\title{
Locus of control and study program choice: evidence of personality sorting in educational choice
}

Citation for published version (APA):

Boone, C. A. J. J., Roijakkers, A. H. W. M., \& van Olffen, W. (2002). Locus of control and study program choice: evidence of personality sorting in educational choice. METEOR, Maastricht University School of Business and Economics. METEOR Research Memorandum No. 006 https://doi.org/10.26481/umamet.2002006

Document status and date:

Published: 01/01/2002

DOI:

10.26481/umamet.2002006

Document Version:

Publisher's PDF, also known as Version of record

\section{Please check the document version of this publication:}

- A submitted manuscript is the version of the article upon submission and before peer-review. There can be important differences between the submitted version and the official published version of record.

People interested in the research are advised to contact the author for the final version of the publication, or visit the DOI to the publisher's website.

- The final author version and the galley proof are versions of the publication after peer review.

- The final published version features the final layout of the paper including the volume, issue and page numbers.

Link to publication

\footnotetext{
General rights rights.

- You may freely distribute the URL identifying the publication in the public portal. please follow below link for the End User Agreement:

www.umlib.nl/taverne-license

Take down policy

If you believe that this document breaches copyright please contact us at:

repository@maastrichtuniversity.nl

providing details and we will investigate your claim.
}

Copyright and moral rights for the publications made accessible in the public portal are retained by the authors and/or other copyright owners and it is a condition of accessing publications that users recognise and abide by the legal requirements associated with these

- Users may download and print one copy of any publication from the public portal for the purpose of private study or research.

- You may not further distribute the material or use it for any profit-making activity or commercial gain

If the publication is distributed under the terms of Article $25 \mathrm{fa}$ of the Dutch Copyright Act, indicated by the "Taverne" license above, 


\title{
Locus of control and study program choice: evidence of personality sorting in educational choice
}

by

\author{
Christophe BOONE \\ Woody VAN OLFFEN* \\ Nadine ROIJAKKERS
}

\author{
Maastricht University \\ Faculty of Economics and Business Administration \\ Department of Organization Studies \\ PO Box 616 \\ 6200 MD MAASTRICHT \\ The Netherlands \\ Tel.: $++31-43-3883880$ \\ E-mail: w.vanolffen@mw.unimaas.nl
}

* Corresponding author; authors appear in alphabetical order. 


\title{
Locus of control and study program choice: evidence of personality sorting in educational choice
}

\begin{abstract}
In this study we investigate whether the process of Attraction Selection and Attrition as described by Schneider (1984) is already operative prior to labor market entry, i.e., in the educational phase of careers. We focused on selection with regard to the locus of control personality trait because of its firm conceptual and empirical relevance in both content and process of choice. Specific hypotheses were proposed as to the sorting of different personality types in study programs leading to different prospective professional careers. The study was carried out in a sample of 164 Austrian students. We found strong support for our hypotheses in that (1) personality predicted specific study choices and (2) personality predicted different levels of rationality in the choice process. In addition, the findings also suggest that tighter matches between personality and study programs could be observed for students making rational choices. The results indicate support for the validity of the ASA model in educational choice, provided the use of meaningful individual differences. Several promising avenues for future research are identified.
\end{abstract}

Key words: ASA-cycle, educational choice, personality, choice processes, individual differences, professional profiles. 


\section{Locus of control and study program choice: evidence of personality sorting in educational choice}

In his seminal 1987 paper, Benjamin Schneider argued that mainstream personality research partly misses the mark because it tends to focus almost exclusively on the impact of individual differences on behavior at the individual level of analysis in very restricted situations (e.g., laboratory conditions). The result is that the potential impact of personality is minimized because the situations studied can generally be characterized as relatively 'strong', leaving no room for individual differences to get expressed. In addition, these studies implicitly assume that individual differences are randomly distributed over situations. Because of this assumption an important question with respect to the effect of individual differences, namely why people find themselves in different situations, has not received the attention it deserves.

Therefore, Schneider made a convincing plea that one should focus more on the dynamic interplay between individual differences on the one hand, and the characteristics, structures and processes of social systems at the system (e.g., organizational) level of analysis on the other hand. People tend to "make the place" not so much because they mold the situation to fit their values

and personality, but rather because of the subtle operation of sorting at higher levels of aggregation. Specifically, because individuals fundamentally differ as to their values, talents and personality (Costa, McCrae, Zonderman, Barbano, Lebowitz and Larson, 1986; Costa and McCrae, 1993), they feel attracted to and actively search for situations that fit their make-up. This attraction process is systematically reinforced because those whose characteristics fit the demands of the situation at hand are selected in while the others are selected out. The end result is that individuals are not randomly distributed over different situations, and that one should be able to detect meaningful relationships between the characteristics of individuals and situations.

This sorting process has been called the Attraction-Selection- $A$ ttrition (ASA) cycle by Schneider, and has mainly been applied in the context of sorting into occupations and organizations in the labor market. In fact, empirical research inspired by Schneider's contribution suggests that due to these selective processes, people within certain occupations and organizations do indeed tend to carry common characteristics that distinguish them from people in other occupations and organizations (Schneider, Brent Smith, Taylor and Fleenor, 1998; 
Schaubroek, Ganster and Jones, 1998). The empirical findings clearly show that this line of research is a promising one, providing new challenges to personality research.

In the present paper we wish to investigate whether similar sorting processes are already operative prior to individuals' labor market entry, in particular when they choose study programs at the university. If the sorting of individuals already starts at the educational phase of a career, different studies attract, select and retain different types of individuals that are subsequently channeled into different career paths. One would, in that case, expect a meaningful relationship between students' personality and the characteristics of the programs they study. This is our first research question, focusing on the outcome of the ASA cycle: are certain types of students overor underrepresented in certain study programs in a predictable way? Next, we wish to go one step further by exploring to what extent a conscious choice process (i.e., attraction) drives this sorting phenomenon. In other words: is the matching process of students to respective study programs facilitated by conscious choice or is the outcome of the ASA process mainly the result of selection and attrition? Ideally, to study the relative importance of attraction on the one hand, versus selection and attrition on the other hand, one needs detailed information on: 1) the preferences of students when they make their study choice in the first place, and 2) the performance and ultimately relative exit rates of students in different study programs as a function of their assumed "fit" with the program. Unfortunately, we do not have this information. However, to explore this interesting question we will investigate: 1) the relationship between personality and the extent to which choices are well-informed and based on relevant information (i.e., "rational") and 2) whether matching of personality and study program is more pronounced when people make conscious (i.e., "rational") choices. If attraction indeed plays a major role in the sorting process one might expect that the matching of individual and program characteristics is facilitated and enhanced the more students make "rational" choices.

The personality trait we chose to study in this respect is the so-called locus of control as developed by Rotter (1966) in his social learning theory (Rotter, 1954). Locus of control refers to relatively stable inter-individual differences in the extent to which events are believed to be under personal control. Individuals believing in internal control ('internals') consider themselves to be masters of their own fate and they have great confidence in their capacity to influence their environments. Internals feel that they can control the occurrence of events in their lives by applying their effort and skills. Individuals believing in external control, by contrast, regard 
themselves as rather passive agents. They consider the occurrence of events in their lives to be due mainly to forces beyond their control and the attainment of valued ends to be dependent primarily on chance, luck, powerful individuals or institutions. Externals do not feel that they can control their lives by means of their own efforts and actions (Lefcourt, 1982). We chose this particular personality characteristic because: 1) internals differ from externals in their capabilities and preferences in such a way that one can expect that certain study programs match internals better than externals and vice versa, and 2) previous research has shown that locus of control is related to the extent to which decision making is informed and well-contemplated (see e.g., Lefcourt, 1982). Replication of this established finding is a secondary objective of the current paper. To our knowledge, this study is the first to explore the role of locus of control sorting in study program choice.

\section{Theory and hypotheses}

Schneider (1987) introduced the idea that "the people make the place" in an endless cyclical process consisting of three related elements, i.e., Attraction, Selection and Attrition. Although his argument can be applied to any kind of sorting into different situations, he focused on how the cycle works in the context of organizations (and to a lesser extent occupations). He argued that, first, people are selectively attracted to the organization's character in terms of its structure, strategy and culture, meaning that certain organizations attract some types of people over others. Next, organizations tend to select, both formally and informally, those individuals that fit the current organizational character over those that do not. Finally, an attrition process occurs over time by which voluntary and involuntary turnover drive out less compatible individuals, whereas those who fit better even adjust more to the dominant profile through socialization. As a result, homogenization of people's characteristics within organizations occurs and is sustained, strengthening the organizations' character (Schneider, Smith, Taylor and Fleenor, 1998). The end result is that organizations are characterized and can be distinguished by the type of people they employ. As said, the same reasoning applies to any sorting in the labor market in general, e.g., with respect to occupations and career tracks (Schaubroek, Ganster and Jones, 1998).

Recent empirical findings support the central proposition following from the ASA model that organizations and occupations are relatively homogeneous with respect to the personality of its 
members (Schaubroek, Gangster and Jones, 1998; Schneider, Smith, Taylor and Fleenor, 1998). For instance, Schneider, Smith, Taylor and Fleenor (1998) used the Myers-Briggs Type Indicator to assess the personality of almost 13,000 managers from 142 organizations and found that a substantial part of variation in personality can be explained by organizational membership. In general, the empirical findings are consistent with the operation of ASA-cycles as they show that different people inhabit different professional environments and careers.

In the present study we wish to extend this line of reasoning by acknowledging that this sorting mechanism might also be operating in relationship to the educational programs young people follow. We expect that students' personality is related to different programs in a predictable way for several reasons. First, students might be indirectly attracted to certain study programs that provide them with prospective career opportunities in certain work environments that fit their personality. Second, a program might have characteristics (e.g., type of curriculum, type of teaching, etc.) that directly attract different persons irrespective of the career opportunities it provides. Finally, apart from attraction, students who do not match the requirements of the program in terms of talents and personality are likely to drop out early.

These general mechanisms of "educational sorting" can easily be translated to the case of locus of control (Rotter, 1966), the personality trait we chose to investigate in this study. A host of past research shows that internals do have very different (professional) capabilities compared to externals (e.g., Lefcourt, 1982; van Olffen, 1999). Specifically, research indicates that internals, as the more self-confident type, have better leadership qualities and managerial skills. In addition, they are much more task-oriented than externals and generally prosper in challenging and uncertain environments. Related to the latter, internals are more stress resistant than externals. Externals on the other hand are more socio-emotionally oriented, follow rather than lead, and prefer and perform better in more structured task environments. It is clear that the prospective occupations of each study program differs considerably as to, for instance, the amount of uncertainty, challenge, and required leadership qualities. We therefore expect that, on average, internals will more than externals prefer and choose programs that provide entry to such "dynamic" occupations. Note that O'Brien (1984) provides evidence that internals are indeed more likely to choose jobs that have higher skill requirements and provide greater personal autonomy. In addition, it is likely that programs preparing students for e.g., uncertain work environments are less structured too, reinforcing not only the process of attraction to certain 
programs but also the extent to which students prosper and perform well in these programs. In this respect it is interesting to mention that internal students have been shown to choose courses that are less structured and require more personal effort (Feather and Volkmer, 1988). To summarize, internals and externals will feel attracted to, and be selected and retained in study programs that match their capabilities. As a result, we expect that:

Hypothesis 1: Compared to externals, internals will be overrepresented in study programs leading to more challenging, uncertain and unstructured future professional environments.

Next, we also analyzed the study choice process of students for two reasons. First, we wanted to replicate previous research on the relationship between locus of control and "rational" decision making (i.e., information search behavior and informed decision making). Second, analysis of the study choice process allows us to explore the relative importance of the attraction phase in the sorting process. Below both hypotheses are elaborated.

In order to make sound choices in an often-confusing environment of information overload, a number of cognitive functions are important. The idea that people's locus of control is related to these cognitive abilities, such as alertness, information search and assimilation is intuitively appealing. Internals should be more cautious and calculating about their choices than externals, as this heightens the probability of successfully regulating behavior in which they trust (Lefcourt, 1982). Empirical research into the relationship between these cognitive abilities and locus of control strongly supports this supposition (van Olffen, 1999). Whether the focus has been on attention, sensitivity, or information assimilation, compared to externals, internals have more often been found to be alert and active individuals who are perceptive to and willing to learn about their environments (Lefcourt and Wine, 1969; Seeman and Evans, 1962; Wolk and DuCette, 1974; Boone, De Brabander and Gerits, 1991). Internals are more inquisitive, more curious, and more efficient processors of information than are externals and are, consequently, more capable of steering themselves through the confusions and vagaries of various situations in a clear and appropriate manner. Externals, by contrast, seem to lack many of the cognitive processes that would allow them to scrutinize their decisions and choices (Lefcourt, 1982). They 
appear to be more led by opportunistic environmental contingencies and show a reactive rather than proactive posture in confronting challenges.

In correspondence with these findings we expect internal students, compared to external students, to be more conscious, cautious and calculating, say: more "rational" ${ }^{1}$, about their study choice. Their choices will be better founded than those of externals. In particular, we expect internals to have shown more active search for information on which to base their choice. In addition, in order to improve their likelihood of being effective in their studies, internal students, compared to external students, are expected to have allowed relevant as opposed to rather opportunistic, irrelevant factors to influence their study choice. Thus, the "rationality" of the study choice process will differ between internals and externals in two related ways as follows.

Hypothesis 2a: Compared to externals, internals will be more likely to have actively searched for information on which to base their study choice.

Hypothesis 2b: Compared to externals, internals will be more likely to have allowed relevant factors to influence their study choice.

Finally, we return to the important question of the extent to which sorting is the result of a conscious, premeditated choice process. In other words: what is the relative importance of attraction in the ASA-cycle? The general proposition is that if attraction is an important precursor of sorting, one should observe closer matching between students and programs when the study choice decision process is relatively "rational". The reason is that the extent to which one feels attracted to a situation (in this case a study program) depends on, according to the ASA-theory, the perceived match between one's personality and the characteristics of that situation. It is clear that such a judgment can only be made with some accuracy when information, and especially relevant information, is available. This leads to our last hypothesis:

Hypothesis 3: The relationship between locus of control and study program choice is stronger for students following more rational (i.e., more active and relevant) decision processes

\footnotetext{
${ }^{1}$ We are aware of undesirable overtones in using this label. Note that we use "rational" here strictly in the sense of choices based on actively obtained information and relevant influencing factors. Its use is pragmatic, as it seems to capture the underlying idea best.
} 


\section{Method}

\section{Sample and data collection}

A questionnaire was submitted to 265 Austrian students of Austria's Leopold-Franzens Universität at Innsbruck. All subjects were in one of the four study programs offered by the Faculty of Social and Economic Sciences: Economics, Business Administration, Business Education, and International Economic and Business Studies. Respondents were distributed over all four years of study. One of the authors was present during lectures in which questionnaires were distributed in order to answer questions students might have. Participation in the study was voluntary and anonymous. This yielded a response of 164 usable questionnaires; the rest was either not returned or filled out incompletely.

\section{Operationalization}

\section{Locus of control}

Locus of control (variable name "Loc") was measured with a German translation of the widelyused and well-known Rotter (1966) Internal-External Locus of Control Scale, which has 23 forced-choice items, 6 of which are filler items. Every item of Rotter's I-E Scale consists of two statements (an external and an internal alternative) and the subjects are to choose between them. The following two statements provide examples of an external and an internal alternative, respectively: "Many times I feel that I have little influence over the things that happen to me", and "It is impossible for me to believe that chance or luck plays an important role in my life". The total locus of control score is obtained by counting the number of external alternatives chosen. High scores, thus, indicate external control orientations and the scale ranges from a minimum of 0 to a maximum of 23. The German translation of Rotter's I-E Scale used in this study contains 14 filler items instead of 6 , in order to make the aim of the test more ambiguous and unclear to the subjects. A number of investigations have shown that this revised version of Rotter's I-E Scale is a valid and reliable measure of locus of control (Boone, de Brabander, Gerits, and Willemé, 1990; Boone, 1992; de Brabander, Boone, and Gerits, 1992; Boone, de Brabander, and 
van Witteloostuijn, 1999b). Cronbach's alpha of the Rotter scale in our sample amounts to .67, which concurs with internal consistencies reported by Rotter (1966) and Robinson and Shaver (1973). Alpha's value is well above the lower limits of acceptability (Nunnally, 1978).

\section{Choice process rationality}

As mentioned in the hypotheses, two aspects of a solidly founded ('rational') choice process were measured, namely how active the search for information was and the relevance of influencing factors on study choice. These were measured as follows.

Active information search behaviour (vs. chance-based decisions).

To measure active information search, three items were taken from a list of information sources to which Austrian students have access, provided by the Österreichische Hochschülerschaft (1997). Specifically: (1) "Before I chose to enroll into a particular study program, I collected information from a study counselor", (2) "I made my study choice to enroll into a particular study program after I collected information from siblings and/or friends who were already in college", and (3) "Before I chose to enroll into a particular study program, I familiarized myself with university life and the various study programs". In contrast, to measure the role of chance-events in choosing a study, three statements were taken from a measure designed and used in a study by Bäumer, Scheller and Maurice (1994), the so called "chance-inventory" ("Zufallsinventar"). These are: (4) "Some information that fascinated me with respect to my study program reached me unexpectedly", (5) "Unexpectedly I met someone who could give me important information about my study program", and (6) "Some unexpected event in my life affected my choice to enroll into a particular study program". These six statements were randomly ordered and students were asked to assign ranks to each according to how important it was in their choice process $(1=$ highest importance; $6=$ lowest importance). The average rank of the active items was calculated and subtracted from 7 to have a positive measure of how active the information search process was.

\section{Choice factor relevance.}

Factors that influence the decision process vary in the amount to which they are of relevance in making a sound and responsible study choice. The following three statements were adapted from a study conducted by the Österreichische Hochschülerschaft (1997) and represent examples of 
factors that should not be allowed to flow into a thorough decision process. They were coded as irrelevant factors with respect to study choice: (1) "I made my choice to enroll into a particular study program based on the fact that my high-school friends made the same choice and I wanted to stay together with them", (2) "I made my choice to enroll into a particular study program under pressure of my parents and/or family members", and (3) "I made my choice to enroll into a particular program based on the fact that the university was situated nearby". On the other hand, the following three factors were adapted from a list of sound study choice determinants ("Berufswahldeterminanten"), included in the study by Bäumer, Scheller and Maurice (1994). These were considered as relevant factors with respect to study choice: (4) "I made my choice to enroll into a particular study program based on my interests", (5) "I made my choice to enroll into a particular study program based on the fact that it would provide an opportunity for selfrealization", and (6) "I made my choice to enroll into a particular study program based on the fact that the career opportunities were good". Again, respondents were asked to rate all factors from most descriptive (1) to least descriptive (6) of their study choice process. The average rank of the relevant items was calculated and subtracted from 7 to have a positive measure of average choice factor relevance.

\section{Study program choice}

Students were asked to indicate which one of the four study programs offered by the Faculty of Social and Economic Sciences they were in. These programs are: (1) Economics, (2) Business Education (BE), (3) Business Administration (BA), and (4) International Economic and Business Studies (IEBS). As only 9 respondents indicated to be in the (general) Economics program, we decided to drop this category from our analyses. Each program educates people in order to be effective in a distinct prospective working environment. For Business Education, this is the classroom and for Business Administration this is general business. Finally, International Economic and Business Studies students are trained to pursue careers in internationally operating businesses and organizations. Common sense suggests that the uncertainty and dynamism of prospective working environments increases from Business Education through Business Administration to International Economic and Business Studies. For instance, it is reasonable to state that the work environment of a teacher, teaching in a local school, is more structured and less dynamic than the environment of a typical international manager who has to work under high 
competitive pressure, has to travel all over the world and to deal with the uncertainties associated with different cultures. In addition, the structure of the IEBS program itself is much more uncertain than the other programs. Every IEBS student has to spend one year of the study at another university abroad, in a non-German speaking country. Consequently, in order to specify hypothesis 1, we expect students' internality to increase in this same order of study programs (i.e., BE, BA and IEBS).

\section{Control variables}

Age and gender were included as control variables. Several studies have indicated sex differences in average locus of control scores. Particularly, men have been found to report more internal control perceptions than women (e.g., Benton, Gelber, Kelley, and Liebling, 1969; Brannigan and Tolor, 1971). With respect to age, it has generally been hypothesized that people believe that they become more capable of obtaining desired satisfactions as they grow older (Lefcourt, 1982). Empirical support for this hypothesized relation between age and locus of control was provided by Bialer (1961) and Penk (1969) who found a positive correlation between age and internality.

\section{Results}

Table 1 reports the descriptive statistics of the variables under study. The sample $(n=164)$ appears to contain about equal numbers of relatively young men and women (mean age $=23.04$, sd $=$ 3.81). Analysis of variance shows that women in the sample $($ mean $=13.82 ; \mathrm{sd}=3.51)$ are significantly $(\mathrm{F}=5.25 ; \mathrm{p}=.025)$ more external than men $($ mean $=12.55$; $\mathrm{sd}=3.56)$. This reaffirms an often-found relationship (e.g., Brannigan and Tolor, 1971) between gender and control perceptions. Locus of control did not appear to be related to age in our sample $(r=-.002)$. Only 25 respondents $(15 \%)$ study Business Education, whereas the rest is almost evenly distributed over the Business Administration and International Economic and Business Studies programs. Note that the average activity with which information on study programs was gathered is close to the midpoint of the scale (mean $=3.61, \mathrm{sd}=.85)$. The relevance of choice factors, on the other hand, have a relatively high average $($ mean $=4.77, \mathrm{sd}=.44)$. Thus, the average student was lead by relatively relevant choice factors, but only moderately active in gathering information. 


\section{INSERT TABLE 1 ABOUT HERE}

The results of testing hypothesis 1 are reported in Table 2 . We conducted 3 separate logistic regression analyses on the choice for either Business Administration, Business Education or International Economic and Business Studies. As hypothesis 1 predicted, locus of control is a significant predictor of the choice to study Business Education and International Economic and Business Studies. Note that the sign of the effects is also as predicted: externals are more drawn to the structured prospective working environments of the Business Education program, whereas internals go for the more unstructured International Economic and Business Studies program and/or the more dynamic careers offered through an IEBS degree. An ANCOVA analysis (with age and gender as covariates) on the locus of control scores of students confirms this picture. A significant difference $(F=5.95 ; p=.003)$ exists between the estimated marginal locus-of-control means of students in Business Education (mean $=14.75$; std error $=.71$ ), Business Administration $($ mean $=13.36$; std. error $=.42)$ and International Economics and Business Studies $($ mean $=11.97$; std. error $=.44$ ). This is precisely the order of personality scores we predicted. Pairwise comparison tests (i.c. Least Significant Differences; not shown here) indicate that all differences are significant at at least $5 \%{ }^{2}$. Note that especially the difference between the IEBS students and the students of the other programs is very large. We conclude that strong support was found for hypothesis 1 .

\section{INSERT TABLE 2 ABOUT HERE}

Table 3 shows regression results ${ }^{3}$ on hypotheses $2 \mathrm{a}$ and $2 \mathrm{~b}$. Internality (i.e., low values on the locus of control scale) appears to be positively associated with both the activity of

\footnotetext{
${ }^{2}$ Note that in Table 2 the non-significance of the LOC coefficient regarding Business Administration is caused by the fact that the average Business Administration LOC score is in between that of Business Education and International Economic and Business Studies. As BA is thus compared to the average of the higher BE and lower IEBS score, it does not reach significance.

${ }^{3}$ We applied OLS regression on rank averages. To test the robustness of these results for violation of normality assumptions we also applied logistic regressions on alternative dependents like dummy variables indicating "at least
} 
information search and the relevance of the involved choice factors. In a word: internals make better-founded study choices than externals do. This confirms both hypotheses $2 \mathrm{a}$ and $2 \mathrm{~b}$. An additional interesting finding in Table 3 is the consistently negative and significant value of the gender variable. Apparently, female students make better-contemplated choices than their male counterparts.

\section{INSERT TABLE 3 ABOUT HERE}

Finally, we tested our explorative hypothesis 3 to see whether personality sorting is more expressed under more consciously made choice conditions. To do so, we reran the logistic regressions of hypothesis 1 for high and low values of information search activity and choice factor relevance. High and low categories were obtained by performing median splits on these variables. This yielded 73 low-activity individuals and 85 high-activity individuals. As the relevance variable is strongly skewed to the right, this procedure unfortunately leads to a rather unbalanced categorization of 50 low-relevance and 108 high-relevance respondents. Note that these 108 students had every relevant information item in their top three. Table 4 shows the resulting coefficients of the locus of control variable for either type of choice process (again controlling for age and gender). ${ }^{4}$

\section{INSERT TABLE 4 ABOUT HERE}

Information gathering activity does not seem to lead to more pronounced personality sorting; regarding Business Education it even seems to reduce it. With respect to the relevance of choice factors employed, however, we do find a result that is in line with the hypothesis. Indeed, personality sorting is more outspoken as study choice is based on more relevant considerations. These latter results are confirmed in an ANCOVA analysis (not shown here) predicting locus of control by study choice under low and high relevance of choice factors (controlling for age and

two relevant (active) items in the top 3" and "entirely relevant (active) top 3". The results, available from the authors upon request, are identical to the ones reported here.

${ }^{4}$ We decided not to use formal interaction tests by including product terms of the decision rationality variables and locus of control in the logistic regressions. The reason is that we never argued that ASA-processes do not work when decision making is less rational. As a result, we only expect that there will be qualitative differences in the extent to which there is a link between locus of control and study program, making strong interaction tests inappropriate. 
gender). The locus of control variance explained by the study program-factor (i.e., eta-squared) is $0 \%$ and $9 \%$ in case of low and high choice factor relevance, respectively. Partial support, as far as the relevance of information is concerned, is therefore found for hypothesis 3 .

\section{Discussion and conclusion}

People and environments are not randomly combined. In the present study we set out to test this central prediction of ASA-theory. If different occupations and/or organizations are characterized by different people, as previous research has shown, one might assert that this sorting is already present when people choose, and are selected in or out of, study programs that channel them into different professions. We did indeed find strong support for personality differences between students in different study programs. Moreover, based on different theoretical "fits" of personalities with characteristics of both the study program itself and of associative features of the prospective working environments, we were able to specify which personality types would be overrepresented in which study program. It should be noted that the effect is not trivial as the size of this personality effect is considerable. For instance, an increase of one standard deviation (i.e, 3.58) in locus of control from its mean almost doubles the base probability of choosing Business Education (from $13 \%$ to $23 \%$ ). A decline of the same magnitude (i.e., more internality) leads to a rise in the base chance of choosing International Business of about one-third (from $39 \%$ to $51 \%)^{5}$. Given the very significant results, our study underscores the importance for the advancement of ASA-theory to use established personality traits with known behavioral consequences. Taken together, the present findings are an important addition to the Schneider et. al. (1998) findings on MBTI personality profiles in different organizational settings because they show that a comparable mechanism is operative even before people enter the labor market. This suggests that the breeding of professional personality profiles is partly accomplished through sorting in the required educational trajectories.

In order to map the choice process leading to these different study choices, we relied on extensive past cognitive research indicating that internals are more knowledgeable and conscious

\footnotetext{
${ }^{5}$ Note that the logistic regression coefficients in Table 2 reflect the marginal change in the natural logarithm of the so-called odds-ratio (i.e., $\mathrm{P} /(1-\mathrm{P})$ with $\mathrm{P}$ being the probability of choosing a certain study). Thus, some basic calculus is involved in reworking the effects to the reported changes in probabilities. Base-rates (15\% and $40 \%$; see Table 1)
} 
decision makers than externals in a variety of situations. We clearly replicated these findings with regard to the study choice process, as internal students based their study program choice on a more active information search process in which relevant instead of rather opportunistic choice considerations dominate: they made the more conscious or "rational" choices.

Finally, to explore the importance of the attraction phase of the ASA-cycle, we analyzed whether we could observe a closer fit between personality and study program for students reporting to have made more conscious and deliberate choices. This appeared to be the case only for the relevance of choice factors involved. Thus, personality has a somewhat greater bearing on study choice when more serious and relevant issues are brought to bear in the process. When revisiting the actual content of the items measuring information relevance (see section 3.2), this result does not come as a surprise. That is, students who base their study choice on whether the program contributes to their "interests" and "provides opportunities for self-realization", (implicitly) discount the qualities associated with their general personality profile into their decision. The result is a closer fit between the latter and study program characteristics. This pattern of findings could not be observed with respect to active versus haphazard information search behavior. This outcome was not expected and is more difficult to explain. However, close examination of the items measuring active information gathering allows us to provide a reasonable ex post explanation. Specifically, it may be that the relevance of the information concerning the content and characteristics of the program does not depend on whether the information was actively or haphazardly gathered. For instance, study program information a student unexpectedly receives from a friend can also be relevant in making a conscious study choice. In this respect it is interesting to mention that there is no significant correlation between the relevant and active choice factor variables $(-.04, \mathrm{~ns}, \mathrm{n}=164)$.

The present study has limitations that point to three important avenues for future research. First, the cross-sectional design of our research does not allow one to unambiguously unravel the importance of the different phases of the ASA-cycle. As a result we were not able to ascertain how exactly the differences in personality between the studies were brought about, apart from stating that conscious choice seems to be involved. In order to shed light on this, longitudinal research is necessary in which different cohorts of students are followed over time. We need to

are somewhat underestimated $(13 \%$ and $39 \%$, respectively) due to accumulation of rounding-errors in the logarithmic transformation. 
have information on preferences prior to study choice and subsequent data on performance and exit rates of "fits" and "misfits". If initial differences in attraction are important in explaining the sorting process, one would expect to observe low drop-out rates. As a result, individual differences between students within the same program would be small in the first place (low variance) and remain rather constant over time. Conversely, when attrition dominates, "misfits" will leave the program, making cohorts of students within the same program more homogeneous over time. Such longitudinal research would also allow one to exclude the possibility that study program choice influences i.e., changes locus of control (or personality in general) rather than the other way around. We think that this is not very likely though, because research has revealed that locus of control is a fundamental, relatively stable personality trait. Miller and Rose (1982) and Pedersen, Gatz, Plomin, Nesselroade and McClearn (1989) have shown that locus of control is to a certain extent inherited. In addition, psycho-physiological findings suggest that locus of control is associated with differences in cerebral functioning (De Brabander, Boone and Gerits, 1992).

Second, we focused on students from a Faculty of Social and Economic Sciences. This of course restricts the range of personality types in our sample. By itself this is not a methodological problem as restriction in range only hampers finding significant differences and thus works against confirming hypotheses. The fact that we $d o$ find large personality differences between programs, points to the importance of the process. Nevertheless, it might be interesting in future research to compare students following very different majors. For instance, Frank, Gilovich and Regan (1993) found that economics students are much less cooperative than students studying other majors, such as psychology. As locus of control has been shown to be related to cooperative behavior (Boone, De Brabander and van Witteloostuijn, 1999a, 1999b) maybe these differences in the tendency to cooperate are related to personality sorting too.

Finally, an implicit assumption of the ASA-theory is that persons who do not match the characteristics of the situation perform less than those who fit. However, as in the present study, this assumption is seldom explicitly investigated. Fortunately, much indirect evidence can be found in the literature. For instance, with respect to locus of control, internals appear to perform better in high managerial positions and in ambiguous situations than externals, whereas externals perform better and show more job satisfaction when the situation is clearly structured (see Boone, 1992; Boone, De Brabander and van Witteloostuijn, 1996). Because the negative consequences of being a "misfit" can be important both in terms of performance and individual well-being, we 
think that more systematic research is required into the mapping of characteristics of situations and individuals, and especially in understanding its consequences. As this type of research helps to avoid the occurrence of "mismatches", it could be of high practical significance. In terms of study program choice, for instance, it is clear that providing students with accurate information on both competencies and personality on the one hand, and requirements of the program on the other hand, would greatly aid students to select environments in which they prosper. 


\section{REFERENCES}

Bäumer, T., Scheller, R., Maurice, J. von (1994)

Der Einfluß von Zufallserfahrungen auf die Studienfachwahl, Swiss Journal of

Psychology, 53(3), 166-177.

Benton, A. A., Gelber, E. R., Kelley, H. H., and Liebling, B. H. (1969)

Reactions to various degrees of deceit in a mixed-motive relationship, Journal of

Personality and Social Psychology, 12, 170-180.

Bialer, I. (1961)

Conceptualisation of success and failure in mentally retarded and normal children, Journal of Personality, 29, 303-320.

Boone, C. (1992)

Onderzoek naar het verband tussen de perceptie van controle van bedrijfsleiders en de strategie en de resultaten van ondernemingen in de meubelindustrie, Unpublished doctoral dissertation, Antwerp: University of Antwerp.

Boone, C., De Brabander, B. and Gerits, P. (1991)

Perception of control and information search strategy in an investment decision game, Perceptual and Motor Skills, 72: 391-398.

Boone, C., Brabander, B. de, Gerits, P., and Willemé, P. (1990)

Relation of scores on Rotter's I-E scale to short-term and long-term control expectancies and fatalism, Psychological Reports, 66, 1107-1111.

Boone, C., De Brabander, B., \& van Witteloostuijn, A. (1996)

CEO locus of control and small firm performance: an integrative framework and empirical test, Journal of Management Studies, 33, 667-699.

Boone, C., De Brabander, B., and van Witteloostuijn, A. (1999a) Locus of control and strategic behavior in a Prisoner's Dilemma game, Personality and Individual Differences, 27, 695-706.

Boone, C., De Brabander, B., and van Witteloostuijn, A. (1999b)

The impact of personality on behavior in five Prisoner's Dilemma games, Journal of Economic Psychology, 20, 343-377.

Brabander, B. de, Boone, C., and Gerits, P. (1992)

Locus of control and cerebral asymmetry, Perceptual and Motor Skills, 75, $131-143$. 
Brannigan, G. G., and Tolor, A. (1971)

Sex differences in adaptive styles, Journal of Genetic Psychology, 119, 143149.

Costa, P.T., Jr., McCrae, R.R., Zonderman, A.B., Barbano, H.E., Lebowitz, B., and Larson, D.M. (1986)

Cross-sectional studies of personality in a national sample: 2. Stability in neuroticism, extraversion, and openness, Psychology and Aging, 1, 144-149.

Costa, P.T., Jr., and McCrae, R.R. (1993)

Set like plaster? Evidence for the stability of adult personality, in T.F. Heatherton en J.L. Weinberger (eds), Can personality change?, Washington: American Psychological Association.

Feather, N.T., and Volkmer, R.E. (1988)

Preference for situations involving effort, time pressure, and feedback in relation to type A behavior, locus of control, and test anxiety, Journal of Personality and Social Psychology, 55, 266-271

Frank, R.H., Gilovich, T., and Regan, D.T. (1993) Does studying economics inhibit cooperation?, Journal of Economic Perspectives, 7, 159-171.

Lefcourt, H. M. (1982) Locus of control: current trends in theory and research, second edition, Hillsdale, New Jersey, Lawrence Erlbaum.

Lefcourt, H. M., and Wine, J. (1969) Internal versus external control of reinforcement and the deployment of attention in experimental situations, Canadian Journal of Behavioural Science, 1, 167-181.

Miller, J.Z., and Rose, R.J. (1982)

Familial resemblance in locus of control: a twin-family study of the internal-external scale, Journal of Personality and Social Psychology, 42, 535-540.

Nunnally, J.C. (1978)

Psychometric theory, Second edition, New York: McGraw-Hill.

O'Brien, G.E. (1984a)

Reciprocal effects between locus of control and job attributes, Australian Journal of Psychology, 36, 57-74.

O'Brien, G.E. (1984b)

Locus of control, work, and retirement. In H.M. Lefcourt (ed), Research with the locus of control construct, Volume 3, New York, Academic Press, 7-68. 
Olffen, W. van (1999)

Team level locus of control and competitive team behaviour - an experimental study, Doctoral dissertation, Maastricht: Datawyse.

Österreichische Hochschülerschaft (1997)

Maturantenwegweiser für ein erfolgreiches Studieren, eine Serviceleistung der ÖH an der Uni Innsbruck.

Pedersen, N.L., Gatz, M., Plomin, R., Nesselroade, J.R., and McClearn, G.E. (1989) Individual differences in locus of control during the second half of the life span for identical and fraternal twins reared apart and reared together, Journal of Gerontology, 44, 100-105.

Penk, W. (1969)

Age changes and correlates of internal-external locus of control scales, Psychological Reports, 25, 856.

Robinson, J. P., and Shaver, P.R. (1973)

Measures of social psychological attitudes, Ann Arbor, MI: University of Michigan, Survey Research Center, Institute for Social Research.

Rotter, J. B. (1954)

Social learning and clinical psychology, Englewood Cliffs, N.J.: Prentice Hall.

Rotter, J. B. (1966)

Generalised expectancies for internal versus external control of reinforcement, Psychological Monographs, 80 (Whole No. 609).

Schaubroek, J., Ganster, D.C. and Jones, J.R. (1998)

Organization and occupational influences in the Attraction-Selection-Attritionprocess, Journal of Applied Psychology, 83, 869-891.

Schneider, B. (1987)

The people make the place, Personnel Psychology, 40, 437-453.

Schneider, B., Brent Smith, D., Taylor, S. and Fleenor, J. (1998)

Personality and organizations: a test of the homogeneity of personality hypothesis, Journal of Applied Psychology, 83, 462-470.

Seeman, M., and Evans, J. W. (1962)

Alienation and learning in a hospital setting, American Sociological Review, 27, 772783.

Wolk, S., and DuCette, J. (1974)

Intentional performance and incidental learning as a function of personality and task dimensions, Journal of Personality and Social Psychology, 29, 90-101. 
Table 1

Descriptives

\begin{tabular}{|c|c|c|c|c|c|}
\hline Variable & $\overline{\mathbf{n}}$ & Mean & SD & "Minimum & "Maximum \\
\hline Age & 158 & 23.04 & 3.81 & 18 & 49 \\
\hline Gender $(0=$ female; $1=$ male $)$ & 164 & .55 & .50 & 0 & 1 \\
\hline Locus of control & 164 & 13.12 & 3.58 & 5 & 20 \\
\hline $\begin{array}{l}\text { Choice process rationality: } \\
\text { - Mean importance of active }\end{array}$ & & & & & \\
\hline $\begin{array}{l}\text { information gathering } \\
\text { - Mean relevance of choice }\end{array}$ & 164 & & .85 & & \\
\hline factors employed & 164 & 4.77 & .44 & 2.67 & 5 \\
\hline Study dummies: & 164 & 45 & 50 & 0 & 1 \\
\hline S2 - Business education & 164 & .15 & .36 & 0 & 1 \\
\hline - S3 - International economics & 164 & .40 & .49 & 0 & 1 \\
\hline
\end{tabular}

Table 2

Study program choice ${ }^{1}$

(hypothesis 1)

\begin{tabular}{||l|l|l|l||}
\hline & \multicolumn{3}{|c||}{ Dependent variables } \\
\hline & $\begin{array}{l}\text { Business } \\
\text { administration }\end{array}$ & $\begin{array}{l}\text { Business } \\
\text { education }\end{array}$ & $\begin{array}{l}\text { International } \\
\text { economics }\end{array}$ \\
\hline & $-4.27^{* *}$ & $-4.40^{*}$ & $6.22^{* * *}$ \\
Constant & $.16^{* *}$ & .02 & $-.23^{* *}$ \\
Age & -.46 & -.53 & $.82^{*}$ \\
Gender & & \\
$(0=$ female; $1=$ male) & & & $-.14^{* *}$ \\
& & $.18^{*}$ & \\
LOC & .04 & & \\
& & & \\
& & $9.47^{*}$ & $28.77^{* * *}$ \\
$\chi^{2}$ & $13.04 * *$ & 125.142 & 185.28 \\
-2 log likelihood & 203.45 & .07 & .13 \\
\hline Pseudo-R & .06 & \\
\hline
\end{tabular}

${ }^{1} \mathrm{n}=158$; logistic regression is applied. The dependent is 1 if the study program is chosen and 0 if it is not. Significance-levels $\uparrow \mathrm{p}<.10{ }^{*} \mathrm{p}<.05 ;{ }^{* *} \mathrm{p}<.01 ; * * * \mathrm{p}<.001$ $\left(\chi^{2}\right.$ tests). 
Table 3

Active information gathering and choice factor relevance ${ }^{1}$

(hypothesis 2a/b)

\begin{tabular}{||l|l|l||}
\hline & \multicolumn{2}{|c|}{ Dependent variables } \\
\hline & $\begin{array}{l}\text { Activity of info } \\
\text { gathering }\end{array}$ & $\begin{array}{l}\text { Relevance of choice } \\
\text { factors }\end{array}$ \\
\hline Constant & $5.24 * * *$ & $5.05^{* * *}$ \\
Age & $-.04 * *$ & .01 \\
$\begin{array}{l}\text { Gender } \\
(0=\text { female; } 1=\text { male })\end{array}$ & $-.25^{*}$ & $-.14 *$ \\
LOC & $-.05^{* *}$ & $-.02^{*}$ \\
S1 & $.32^{*}$ & $-.10 \dagger$ \\
S2 & -.05 & .10 \\
F & $3.78^{* *}$ & $2.34 *$ \\
$\mathrm{R}^{2}$ & .11 & .07 \\
\hline \hline
\end{tabular}

${ }^{1} \mathrm{n}=158$; OLS regression coefficients are reported. One-tailed significance levels: $\uparrow \mathrm{p}<.10 ; * \mathrm{p}<.05 ; * * \mathrm{p}<.01 ; * * * \mathrm{p}<.001$ (t-tests).

Table 4

Personality-effects on study choice under low and high choice process rationality ${ }^{1}$

(hypothesis 3)

\begin{tabular}{||l|l|l|l||}
\hline & \multicolumn{3}{|c|}{ Dependent variables } \\
\hline & $\begin{array}{l}\text { Business } \\
\text { administration }\end{array}$ & $\begin{array}{l}\text { Business } \\
\text { education }\end{array}$ & $\begin{array}{l}\text { International } \\
\text { economics }\end{array}$ \\
\hline $\begin{array}{l}\text { Activity of info } \\
\text { gathering } \\
\text { low }(n=73) \\
\text { high }(n=85)\end{array}$ & .05 & & \\
$\begin{array}{l}\text { Relevance } \\
\text { choice factors } \\
\text { low }(n=50) \\
\text { high }(n=108)\end{array}$ & .09 & $.26^{*}$ & $-.20^{*}$ \\
& .03 & & $-.14^{*}$ \\
& .03 & .09 & -.11 \\
\hline
\end{tabular}

${ }^{1}$ Logistic regression coefficient of the locus of control variable under either condition is reported, controlling for age and gender. Significance levels: ${ }^{*} \mathrm{p}<.05\left(\chi^{2}\right.$ tests). 